\title{
Heights and Weights of Preschool Children Visiting the MCH Clinic of the General Hospital (RSUPP), Medan *
}

by

I.EMAN SEMBIRING, LEONARD NAPITUPULU and S.M. MANOEROENG

(Department of Child Health, Medical School University of

North Sumatera, Medan)

Abstract

The average height and weight of 4,082 children visiting the General Hospital (RSUPP), Medan, throughout $1969-1974$ were higher than that reported by Sukonto et al. (1939). However, the heights and weights of school children at 5 to 6 years as reported by Hartaman et al. (1973) were higher than our findings in this study. Compared with the U.S. growth charts the height of these children was very close to the 10th percentile, while the weight was between the $3 \mathrm{rd}$ and the 10th percentile of the Harvard standard. At birth the average iveigni was very ciose to the 50th percentile of the Harvard standard, at one year it was very close to (below) the 10th percentile, while at 2-5 years it was slightly above the $3 r d$ percentile.

* Presented at the Sccond Asian Congress of Pediatrics, Jakarta, 3-6 August, 1976.

Received 13th. Nov., 1976. 


\section{Introduction}

Data on height and weight meen. ments are of practical importance for the assessment of growth of children. They established the relationship between higher socio-economic levels and growth rates. For instance, well-nourished Africans, Japanese, Chinese, Filipinos (WHO, 1969), Turkish (Neyzi et al., 1973), etc. approach remarkably close to U.S. standards. Growth rates in different areas within a country enable comparison of the overall nutritional situation in the areas in question (WHO, 1969),

This study was carried out with the following objectives:

1. To find some parameters of growth (height and weight) of preschool children visiting the $\mathrm{MCH}$ clinic of RSUPP, Medan.

2. To compare these figures with available data in Jakarta, Indonesia (Sukonto, 1939) and wesiern countries (Harvard standards).

\section{Materials and Methods}

A 6-year (1969 - 1974) retrospective study was made on 4,082 preschool children visiting the $\mathrm{MCH}$ clinic of RSUPP Medan, i.e. 222 (1969), 223 (1970), 693 (1971), 991 (1972), 1074 (1973), and 879 (1974). However, only 420 children (196 males and 224 females) had 4 or more visits in the groups recommended by the Western Pacific Region of the WHO, i.e. 12 months, 15 months, 18 months, $9+4 . . .$. nths, 2 years, $21 / 4 n \pi n$. $-1 / 2$ years, 4 years. $41 / 2$ years, 5 years, $51 / 2$ years and 6 years (WHO, 1969). $\Rightarrow i$

The heights and weights notrenchildren who were able to stand steadily were measured with a Detecto beam balance scale equipped with height measurement. Younger children who were unable to stand steadily were weighed with a Detecto beam balance scale and their recumbent lengths were measured with the ordinary type of wooden measuring-staff. All of these measurements were done by 3 midwives, following the standard procedures of measuring weight and height as recommended by Jelliffe (1969). All cases were subjected to a brief physical examination. Subjects who showed signs of clear-out malnutrition were excluded from the group.

Most of the children were born in the Department of Obstetrics, RSUPP Medan, and had a birth certificate where the birth weight was also recorded. The remainder was born either in other maternity hospitals in Medan or at home; their birth weights were recorded according to interviews with the mothers. Only 378 out of 420 children were with birth weights, comprising 177 males and 201 females.

\section{Results}

The average birth weight of the 378 children, based on the birth certificate and interview with the mothers, was $3.27 \mathrm{~kg}$. in male and $3.22 \mathrm{~kg}$. in female 


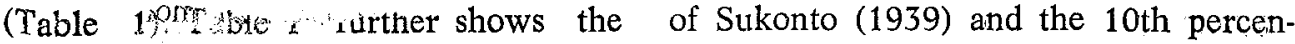
average height and weight in the age tiles of the Harvard standards is recorgroup of 12 months; 15 months, etc. up ded in Tables 2 and 3, while the grato $i$ years. The comparison of the height phical comparison of these figures is an. wht of hese children with those shown in Figures 1 and 2.

TABLE 1: Height and weights of preschool children attending the $M C H$ clinic by age and sex expressed in Mean and S.D.

\begin{tabular}{|c|c|c|c|c|c|c|c|c|}
\hline \multirow{2}{*}{ Age group } & \multicolumn{4}{|c|}{$\mathrm{H}$ e i g l t in c m. } & \multicolumn{4}{|c|}{ We ig h $\mathrm{t}$ in $\mathrm{kg}$. } \\
\hline & \multicolumn{2}{|c|}{ male } & \multicolumn{2}{|c|}{ female } & \multicolumn{2}{|c|}{ male } & \multicolumn{2}{|c|}{ female } \\
\hline Birth & - & & - & & 3.27 & - & 3.22 & 一 \\
\hline 12 months & 72.30 & 2.15 & 70.50 & 2.79 & 8.68 & 0.86 & 8.46 & 0.82 \\
\hline 15 months & 77.34 & 3.44 & 74.62 & 2.80 & 8.93 & 0.97 & 8.55 & 1.00 \\
\hline 18 months & 80.66 & 3.57 & 79.24 & 2.99 & 9.72 & 0.91 & 9.13 & 0.92 \\
\hline 21 months & 82.66 & 3.66 & $81: 00$ & 3.37 & 9.95 & 1.11 & 9.68 & 1.11 \\
\hline 2 years & 83.71 & 3.77 & 82.50 & 3.29 & 10.44 & 1.15 & 10.42 & 0.67 \\
\hline $21 / 2$ years & 86.19 & 4.23 & 85.92 & 2.74 & 11.40 & 1.23 & 11.10 & 1.07 \\
\hline 3 years & 91.01 & 3.40 & 90.13 & 4.07 & 12.46 & 1.25 & 11.96 & 1.57 \\
\hline $31 / 2$ years & 94.56 & 4.22 & 94.47 & 4.67 & 12.82 & 1.11 & 12.98 & 1.43 \\
\hline 4 years & 98.02 & 4.40 & 97.50 & 3.85 & 14.15 & 1.3 .2 & 13.76 & 1.44 \\
\hline $41 / 2$ years & 101.81 & 4.13 & 100.90 & 3.59 & 15.07 & 1.43 & 14.68 & 1.28 \\
\hline 5 years & 103.60 & 4.70 & 102.31 & 3.70 & 15.98 & 1.42 & 15.03 & 1.59 \\
\hline $51 / 2$ years & 106.52 & 4.15 & 105.70 & 4.84 & 16.50 & 1.27 & 15.98 & 2.03 \\
\hline 6 years & 109.00 & 5.40 & 109.44 & 4.75 & 17.42 & 1.46 & 17.00 & 2.23 \\
\hline
\end{tabular}


TABLE 2: Comparative weights of preschool children in Medan, Jakurta 1939); and the 10th percentile of Harvard standards by age and sex

\begin{tabular}{|c|c|c|c|c|c|c|}
\hline & \multicolumn{3}{|c|}{ M a 1 e } & \multicolumn{3}{|c|}{ F e m a l e } \\
\cline { 2 - 7 } Age in years & $\begin{array}{c}\text { Medan } \\
(1976)\end{array}$ & $\begin{array}{c}\text { Sukonto } \\
\text { (Jakarta } \\
1939)\end{array}$ & $\begin{array}{c}\text { 10th perc. } \\
\text { Harvard }\end{array}$ & $\begin{array}{c}\text { Medan } \\
(1976)\end{array}$ & $\begin{array}{c}\text { Sukonto } \\
\text { Jakarta } \\
1939)\end{array}$ & $\begin{array}{c}\text { 10th perc. } \\
\text { Harvard }\end{array}$ \\
\hline 1 & 8.68 & 8.1 & 8.89 & 8.46 & 7.6 & 8.55 \\
2 & 10.44 & 9.6 & 11.2 & 10.42 & 9.3 & 10.66 \\
3 & 12.46 & 11.4 & 13.02 & 11.96 & 11.0 & 12.52 \\
4 & 14.15 & 13.0 & 14.56 & 13.76 & 12.6 & 14.15 \\
5 & 15.98 & 14.4 & 16.1 & 15.03 & 14.2 & 15.79 \\
6 & 17.42 & 15.8 & - & 17.0 & 16.2 & - \\
\hline
\end{tabular}

TABLE 3: Comparative heights $(\mathrm{cm}$.) of preschool children in Medan, Jakarta (Sukonto 1939), and the 10th percentile of Harvards by age and sex

\begin{tabular}{|c|c|c|c|c|c|c|}
\hline & \multicolumn{3}{|c|}{ M a 1 e } & \multicolumn{3}{c|}{ F e m a l e } \\
\cline { 2 - 7 } Age in years & $\begin{array}{c}\text { Medan } \\
(1976)\end{array}$ & $\begin{array}{c}\text { Sukonto } \\
\text { (Jakarta } \\
1939)\end{array}$ & $\begin{array}{c}\text { 10th perc. } \\
\text { Harvard }\end{array}$ & $\begin{array}{c}\text { Medan } \\
(1976)\end{array}$ & $\begin{array}{c}\text { Sukonto } \\
\text { (Jakarta } \\
1939)\end{array}$ & $\begin{array}{c}\text { 10th perc. } \\
\text { Harvard }\end{array}$ \\
\hline 1 & 72.3 & 71.3 & 72.4 & 70.5 & 71.3 & 70.6 \\
2 & 83.7 & 79.4 & 84.2 & 82.5 & 78.4 & 82.6 \\
3 & 91.0 & 86.4 & 92.3 & 90.1 & 85.3 & 90.5 \\
5 & 98.0 & 93.5 & 99.3 & 97.5 & 92.5 & 97.6 \\
6 & 103.6 & 101.9 & 103.7 & 102.3 & 100.0 & 103.0 \\
\hline
\end{tabular}


Inith wis

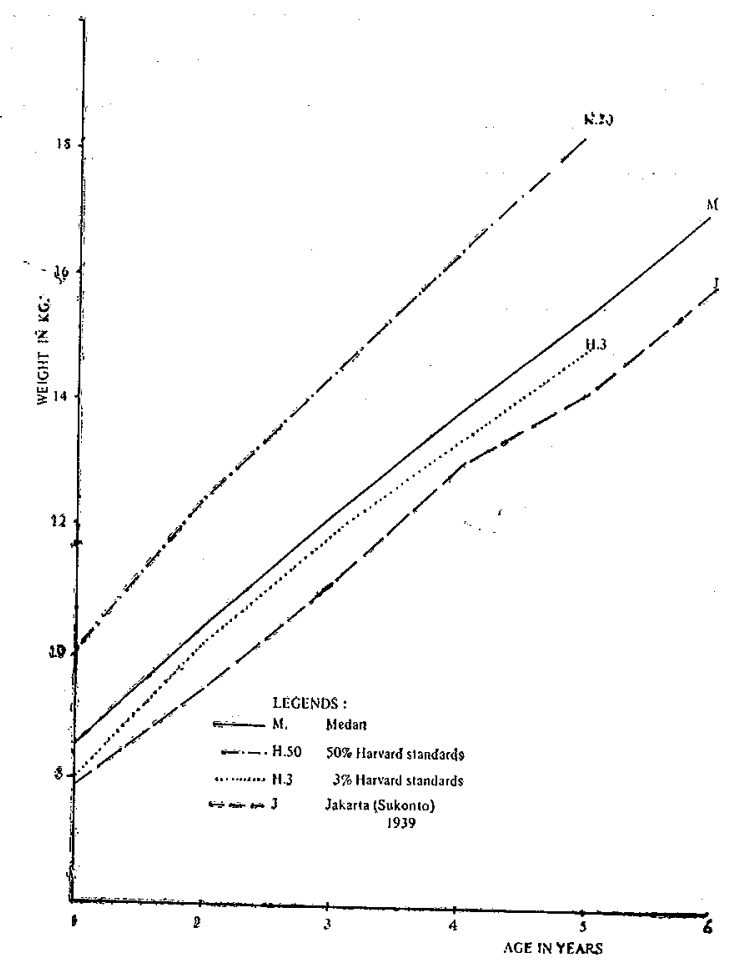

FIG. 1 .

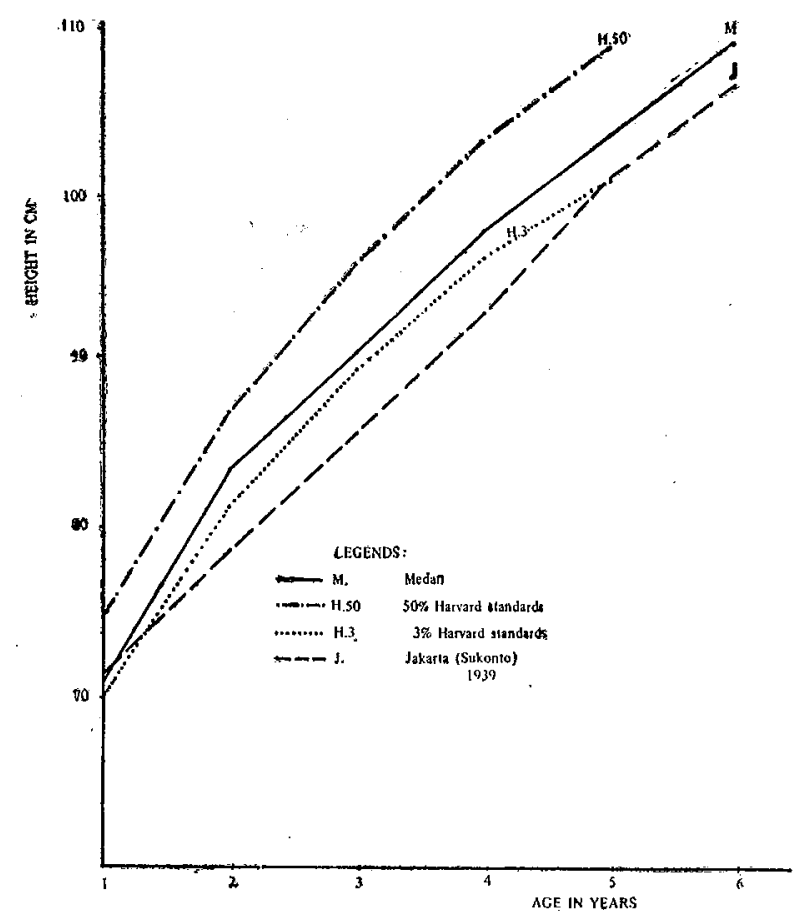

FIG 2. 


\section{Discussion}

The average birth weight of these children was similar to our previous study (Manoeroeng et al., 1974). The average height and weight of every age group were higher than those reported by Sukanto (1939) as shown in Tables 2 and 3 in both sexes. It was probably due to some improvement of nutritional situation or other environmental factors, because it is believed that the low height and weight values in developing countries are the results of environmental influences rather than genetic characteristics of the samples (Neyzi et al., 1973). However, heights and weights of the children as reported by Hartaman et al. (1973) were higher than our figures. Compared with the North American growth charts, the heights and weights of these children fell between the 3rd and 10th percentile of the Harvard standards (Nelson, 1975).

In afluent countries, the growth of the children is at the optimal rate. For instance, at one year of age the birth weight is tripled, at $2 \frac{1}{2}$ years of age the birth weight is quadripled, and at 5 years of age the weight at one year is doubled (Slobody and Wasserman, 1968). However, in our case the weight at one year of age was less than three times the birth weight, at $2 \frac{1}{2}$ years of age it was less than weight, and at 5 years of is less than twice the weight T. Whar. In other words, the growth culve is flatter than that of western countries.

At birth the average weight was very close to the 50th percentile of the Harvard standard, at one year it was very close to (below) the 10th percentile. while at $2-5$ years it was slightly above the 3rd percentile. This probably means that our preschool children did not attain their optimal growth, since any given physical measurement usually follows a canstant percentile channel in the course of healthy growth (Slobody and Wasserman, 1968). The average gain in height in American children is about $12 \mathrm{~cm}$. in the 2nd year, while during the $3 \mathrm{rd}, 4 \mathrm{th}$, and 5 th year of life it is about $8.6 \mathrm{~cm}$.

In our material, however, the average height gain in the 2 nd year of life was slightly lower than that of the American children, i.e. $11.7 \mathrm{~cm}$. In the $3 \mathrm{rd}, 4$ th and 5 th year of life it was also slightly lower than that of the American children, i.e. $7.5 \mathrm{~cm} ., 7.2 \mathrm{~cm}$. and $5.2 \mathrm{~cm}$. respectively. The height of these children was approximately higher than that of Sukonto (1939), except at 1 year of age in the females which was 70.5 and $71.3 \mathrm{~cm}$. respectively. 


\section{REFERENCES}

HART.. $\quad \therefore$ AZHALI, M.S. and HENDRA; : Body weight and height of school chidren in Bandung. Paediatr. indones. 13 : 293 (1973).

2. JELLIFFE, D.B. : The assessment of the nutritional status of the community. W.H.O. Monograph series no. 53, Geneva (1969).

3. MANOEROENG, S.M.; SEMBIRING, L. and TARIGAN, Sj. : Growth and development of irfants in the first year of life. Konika III, Surabaya, Indonesia (1974).

4. NELSON, W.A.: Textbook of Fediatrics 10 th ed., p. 13 (Saunders, Philade'phia 1975).
5. NEYZI, C.; YAICINDAG, A. and ALP, H. : Heights and weights of Turkish children. Environ. Child Health 19:5 (1973).

6. SLOBODY, L.B. and WASSERMAN, E.: Survey of clinical pediatr. 5th ed. (McGraw-Hill, New York 1968).

7. SUKONTO : The growth of children of preschool age in Batavia. Indian J. Pediatr. $6: 163$ (1939). Cited from Kumpulan Kuliah Ilmu Kes. Anak, FKUl, jilid I, cetakan ke-II (1974). In Indonesian Language.

8. The Health Aspects of Food and Nutrition; a manual for developing countries in the Western Pacific of the W.H.O., Manila (1959). 